Research Article OPEN OACCESS

\title{
Assessing Levels of Hazardous Metals in Soil and Medicinal Plant Samples from Asafo, Suame and Asante-Mampong Auto-Mechanic Workshops
}

\author{
Emmanuel Dartey*, Kofi Sarpong
}

Faculty of Science and Environment Education, University of Education, Winneba, Asante-Mampong, Ghana

"Corresponding Author: Dr. Emmanuel Dartey, Faculty of Science \& Environment Education, University of Education, Winneba, P.O.BOX 40, Mampong-Ashanti, Ghana, E-mail: emmldartey@yahoo.co.uk

Citation: Dartey, E., et al. Assessing Levels of Hazardous Metals in Soil and Medicinal Plant Samples from Asafo, Suame and Asante-Mampong Auto-Mechanic Workshops. (2015) J Environ Health Sci 1(4): 1- 6.

\author{
Received date : October 01, 2015
}

Accepted date : November 30, 2015

Published date: December 05, 2015

\begin{abstract}
Contents of hazardous metals $(\mathrm{Pb}, \mathrm{As}$ and $\mathrm{Cd})$ were assessed in medicinal plants and soil samples from auto-mechanic workshops and background soils in Suame and Asafo suburbs of Kumasi and Asante-Mampong the administrative capital of Mampong - Municipal, Ghana with Atomic Absorption Spectrophotometer. Geo-accumulation index $\left(\mathrm{I}_{\text {geo }}\right)$ by Muller was employed to determine the extent of contamination. SAWS was uncontaminated with As $\left(\mathrm{I}_{\mathrm{geo}}=-2.43\right)$, "moderately to heavily contaminated" with $\mathrm{Pb}\left(\mathrm{I}_{\mathrm{geo}}=2.79\right)$ and $\mathrm{Cd}\left(\mathrm{I}_{\mathrm{geo}}=2.26\right)$. MAWS was uncontaminated with $\mathrm{Pb}\left(\mathrm{I}_{\mathrm{geo}}=0.02\right), \mathrm{Cd}\left(\mathrm{I}_{\mathrm{geo}}=0.69\right)$ and As $\left(\mathrm{I}_{\mathrm{geo}}=-1.38\right)$. AAWS was "moderately to heavily contaminated" with $\mathrm{Pb}\left(\mathrm{I}_{\text {geo }}=2.84\right)$ and $\mathrm{Cd}\left(\mathrm{I}_{\mathrm{geo}} \stackrel{\text { geo }}{=1.18)}\right.$ but uncontaminated with $\mathrm{As}\left(\mathrm{I}_{\mathrm{geo}}=-1.38\right)$. The mean concentration range of $\mathrm{Pb}$ recorded for medicinal plants samples at SAWS $\left(2.48\right.$ - 38.97) $\mu \mathrm{gg}^{-1}$, AAWS (1.64 - 18.16) $\mu \mathrm{gg}^{-1}$ and MAWS (5.92 - 19.24) $\mu \mathrm{gg}^{-1}$ were above the normal medicinal plant $\mathrm{Pb}$ concentration $\left(0.2 \mu \mathrm{gg}^{-1}\right)$ but below the critical plant concentration (30 - 300) $\mu \mathrm{gg}^{-1}$ with the exception of Terminalia catappa at SAWS. Mean Cd and As levels recorded at SAWS, AAWS and MAWS were within the normal range of medicinal plant $C d$ and As concentration of $(0.1-2.4) \mu g^{-1}$ and $(0.02-7) \mu g^{-1}$ respectively.The analysis of transfer factor, which was calculated as the ratio of hazardous metal concentrations in medicinal plant to those in the corresponding soil, indicated the uptake capabilities of hazardous metals from soil to medicinal plant.The highest transfer ratios of $\mathrm{Pb}(0.38$ - 33.58) was recorded at MAWS while As $(0.25$ - 2.92) and $\mathrm{Cd}(0.95-4.07)$ was measured at SAWS.
\end{abstract}

Keywords: Hazardous metal; Medicinal plants; Geo-accumulation index $\left(\mathrm{I}_{\mathrm{geo}}\right)$; Transfer ratio

\section{Introduction}

Hazardous metals are widely distributed in the Earth's crust and are classified among serious pollutants within the natural environment. Recently, the presence of hazardous metals in the ecosystem has become a global concern due to the perilous effects they pose to humans and other organisms when allowable limits are exceeded, persistence and potential bioaccumulation. Hazardous metals are capable of decreasing crop production due to the risk of bioaccumulation and biomagnifications in the food chain (Wuana and Okieimen, 2011). Reports on dangers exhibited by $\mathrm{Fe}, \mathrm{Pb}, \mathrm{Cr}, \mathrm{Zn}, \mathrm{Cu}$ and presence in soils have been documented (Akoto et al., 2008). Natural activities such as atmospheric deposition and weathering contribute to the amount of hazardous metals in the vicinity. Through weathering from natural rock formations they spread widely in the environment, occurring in particulate or dissolved form in soils, water bodies and sea floor sediments. Volcanoes also release hazardous metals into the atmosphere. For example $\mathrm{Cd}$ enters the atmosphere through natural processes such as weathering and a volcanic emission is then deposited by precipitation into water bodies. These toxic chemicals can enter the environment through anthropogenic sources like application 
of fertilizers, agrochemicals and other substances employed for soil amendment (Sofianska et al., 2013 and Senesi et al., 1999). Auto-mechanic workshops are perceived as sources of environmental hazardous metal pollution as activities such as welding and soldering, painting, repairing of lead accumulator cells by mechanics release hazardous metals into the environment (Pam et al., 2013). The disposal of spent lubricating oil, used vehicle brake parts, galvanized parts like fuel tanks and burning of tires increase the quantity of these toxic substances. Indiscriminate disposal of used computers and other electronic gadgets from electronic or auto-electrical workshops also accounts for the presence of hazardous metals in the environment. Once released into the ecosystem they can be washed into water bodies (both underground and surface) during rainfall affecting water quality and biota. According to Schmitt \& Brumbaugh, 1990, whole fish samples from 109 streams in United States revealed high $\mathrm{Zn}$ and $\mathrm{Cu}$ content from Manoa streams.

Seventy percent of Ghanaians employ medicinal plants and other herbal products for the management of both complex and simple diseases. Ghana's doctor- patient ratio is approximately 1:15, 259 patients per year (Citifmonline.com, 2014). The high doctor-patient ratio in the country reduce quality of care patients receive from doctors. Other health care workers such as "physician assistants" attend to 38,000 per year. Midwives and nurses also attend to 6000 and 1400 patients respectively in a year (Citifmonline.com, 2014). The current high costs of medical care and living in Ghana are fertile grounds to force patients to employ medicinal plants/herbal products to treat diseases. Traditional Medicine Practitioners are found in most Ghanaian communities (CDIP, 2014) making them more accessible to the patients.

Inhabitants of Suame, Asafo and Asante- Mampong and neighboring towns employ medicinal plants located at the auto-mechanic workshops to treat their ailments. Studies undertook by researchers had revealed high content of hazardous metals such as $\mathrm{Pb}, \mathrm{Cd}$ and $\mathrm{As}$ in auto-mechanic workshop soil (Adewole and Uchegbu, 2010). Medicinal plants absorb hazardous metals, store them in their tissues and are transferred to humans and other organisms through continuous ingestion (O'Neil, 1990). Elevated hazardous metal concentration in the raw materials and soils may imply that consumers are ingesting toxic chemicals which are deleterious to their health. Since limited study had been embarked upon to assess the extent of contamination of medicinal plants and soils at the auto-mechanic workshop the current was carried out.

\section{Materials and Methods}

\section{Study Areas}

The study was carried out at Suame and Asafo auto-mechanic Workshops, Kumasi and Mampong auto-mechanic Workshop at Asante- Mampong. Kumasi $\left(6^{0} 35^{\prime} \mathrm{N}-40^{\prime} \mathrm{N}\right.$, $1^{\circ} 30^{\prime} \mathrm{W}$ ) is the capital town of Ashanti Region of Ghana and is situated at 250-300 m above sea level. It is the second most populous city after the nation's capital, Accra. It is estimated to have a population of two million, twenty-two thousand nine hundred and nineteen $(2,022,919)$ and covers an area of two hundred and fifty-four square kilometers $\left(254 \mathrm{~km}^{2}\right)$. Suame auto-mechanic Workshop is made up of a cluster of Micro-, Small- and Medium- Scale enterprises with specialty mainly in vehicular repairs and metal works. It occupies an area of 20 square miles. There are about 12,000 businesses and a work force of about 200,000. Asafo auto-mechanic workshop is also popular but covers a smaller area in comparison to Suame, but larger than Mampong auto-mechanic workshop. Asafo auto-mechanic workshop had a working population of 12,000 . Mampong is the administrative capital of Asante-Mampong of Sekyere - West Municipal Assembly. Besides the sale of vehicular spare-parts, repair of lead accumulator cells, engineering materials, welding and other artisanal work are many women who sell food at these sites (Dartey et al., 2014). Mampong is $50 \mathrm{~km}$ north of Kumasi. The municipality is located within longitudes $0^{\circ} 05^{\prime \prime} \mathrm{W}$ and $1030^{\prime \prime} \mathrm{W}$ and latitudes $6^{0} 55^{\prime \prime} \mathrm{N}$ and $7^{\circ} 30^{\prime \prime} \mathrm{N}$, covering a total land area of about $2346 \mathrm{~km}^{2}$ with a population more than 88,000 (Ghana districts, 2012).

\section{Sample Collection, Pretreatment and Analysis}

Soil samples were collected at (0 to 0.15$) \mathrm{m}$ depth at the selected auto-mechanic sites since according to (Krishna \& Grovil, 2007) hazardous metals contaminate top layer of soils at a depth of $(0$ to $0.40 \mathrm{~m})$. Ten representative soil cores and medicinal plant samples (bark) were collected (Agyarko et al., 2010). This process was repeated at background sites (1000 m away). Medicinal plant samples were obtained from where soil samples were obtained. Medicinal plants samples were washed with distilled water to free them from contaminants. They were solar dried for 72 hours, crushed with a wooden mortar and pestle and sieved using a $2 \mathrm{~mm}$ mesh. Collected soil samples were solar dried for 48 hours and crushed down with pestle and mortar. They were sieved using $2 \mathrm{~mm}$ mesh. Soil and medicinal plant samples were kept in polyethene bags. Samples were placed in well labeled plastic bottles and transported to Center for Scientific and Industrial Research (CSIR) - Soil Research Institute (SRI), Kwadaso, Kumasi for analysis.

Digestion and analysis were carried out at Council for Scientific and Industrial Research -Soil Research (CSIR-SRI) at Kwadaso, Kumasi, Ghana. Dry Ashing method of digestion was adopted from the protocol of Perkin -Elmer manual for atomic absorption spectrophotometry. This involved weighing $8 \mathrm{~g}$ each of the selected medicinal plant samples into crucibles made of porcelain. The contents of crucibles were dried at $110^{\circ} \mathrm{C}$ and moistened with magnesium nitrate $(50 \% \mathrm{w} / \mathrm{v})$. Ashing started immediately in a controlled muffle carbolated furnace at a temperature of $450^{\circ} \mathrm{C}$ and left overnight to ensure complete oxidation of organic components of the sample. The ash of each sample was dissolved in $20 \mathrm{ml}$ of concentrated nitric $\left(\mathrm{HNO}_{3}\right)$ and perchloric $\left(\mathrm{HClO}_{4}\right)$ acids in a ratio of 9:4 in a $200 \mathrm{ml}$ digestion tube. It was then heated in a block digester to allow thorough dissolution of ash in acid. Heating continued until the brown fume of nitric acid ceased and the sample turned clear. The digestion was stopped and distilled water added to obtain a total volume of $20 \mathrm{ml}$. The final solution was filtered through a $0.45 \mu \mathrm{m}$ pore size membrane filter paper (Whatman filter paper No. 41) to obtain a particle-free solution. Heavy metal concentration were determined (in triplicates) using VARIAN SPECTRA AA220 Zeeman Atomic Absorption Spectrometer (AAS) (Varian Canada Inc). The instrument setting and operational conditions were in accordance with the manufacturers specifications. 


\section{Data analysis}

The geo-accumulation index, (I-geo) was employed to evaluate the extent of pollution of hazardous metals in soil samples. The geo-accumulation index relation employed was:

$\mathrm{I}_{\text {geo }}=\log _{2}\left(\mathrm{C}_{\mathrm{n}}\right.$ Sample $\left./ 1.5 \times \mathrm{B}_{\mathrm{n}}\right) \quad($ Muller, 1969)$)$.

Where,

$\mathrm{C}_{\mathrm{n}}=$ measured concentration of metal in the soil $\left(\mu \mathrm{gg}^{-1}\right)$

$\mathrm{B}_{\mathrm{n}}=$ background value of heavy metal in $\mu \mathrm{gg}^{-1}$; and $1.5=$ background matrix correction factor.

The transfer factor is the ratio of the concentration of a specific metal in the plant to the measured concentration of that metal in the soil (Agyarko et al., 2010; Chojnacka et al., 2005).

\section{Results and Discussion}

\section{Soil Metal Content}

Soil is regarded as an important resource for providing fundamental human needs, food and habitable environment (Wild, 1995). Rural and urban soils may accumulate hazardous metals released into the ecosystem. These hazardous metals are non-biodegradable and persist in the soil for a long time (Kirpichtchikova et al., 2006). Accumulated hazardous metals beyond permissible levels through anthropogenic activities have adverse effects on organisms (D'Amore et al., 2005). Soils from the study areas exhibited variation in $\mathrm{Pb}, \mathrm{Cd}$ and As contents (Table 1). It could be inferred that auto-mechanic workshop soils had higher metal load in relation to the background soils with the exception of few. Lead is a poisonous hazardous metal with retention time 150- 5000 years (Sobolev and Begonia, 2008). While AAWS contained the highest $\mathrm{Pb}$ content $(161.07 \mu \mathrm{gg}$ $\left.{ }^{1}\right)$, the lowest $\left(6.62 \mu \mathrm{gg}^{-1}\right)$ was obtained in SBS and ABS. Both MAWS and MBS recorded $\mathrm{Pb}$ amounts $\left(17.63 \mu \mathrm{gg}^{-1}\right)$ and (11.54 $\left.\mu \mathrm{gg}^{-1}\right)$ respectively. Soil $\mathrm{Pb}$ levels $\left(6.62\right.$ - 169) $\mu \mathrm{gg}^{-1}$ was within the normal range values for soil $\mathrm{Pb}(2-300) \mu \mathrm{gg}^{-1}$ (Radojevic and Bashkin, 2006).

Cadmium concentration $\left(2.10 \mu \mathrm{gg}^{-1}\right)$ the highest among the soil samples was observed in AAWS. Suame auto-mechanic workshop and ABS had same Cd level $\left(0.43 \mu \mathrm{gg}^{-1}\right)$. Cadmium content in the rest of the samples was SBS $\left(0.03 \mu \mathrm{gg}^{-1}\right)$, MAWS $\left(1.80 \mu \mathrm{gg}^{-1}\right)$ and $\operatorname{MBS}\left(0.60 \mu \mathrm{gg}^{-1}\right)$.

Arsenic is a toxic metal with no known function in the human body. If the rate of accumulation becomes higher than the body's ability get rid of the metals they become toxins. Ingestion of sub-lethal doses of As may result in bone marrow depression and haemolysis (IPCS, 1980). Arsenic amounts (0.11 - 1.80) $\mu \mathrm{gg}^{-1}$ fell within $\left(0.1\right.$ - 40) $\mu \mathrm{gg}^{-1}$ the normal range for soil As. Asafo auto-mechanic workshop soil had highest As content $\left(1.80 \mu \mathrm{gg}^{-1}\right)$ while a lowest value $\left(0.11 \mu \mathrm{gg}^{-1}\right)$ was recorded in MWS. Suame background soil (SBS) and ABS unusually had higher As content $\left(0.91 \mu \mathrm{gg}^{-1}\right)$ than SAWS $\left(0.12 \mu \mathrm{gg}^{-1}\right)$ and MBS $\left(0.29 \mu \mathrm{gg}^{-1}\right)$.

Emissions from vehicles are deemed as a major source of contamination at auto-mechanic workshops (Adriano, 2001). Repairs and servicing, spraying of vehicles, welding and soldering, auto body straightening, metal scraps disposal contribute to release of hazardous metals. In lead accumulator cells $\mathrm{Pb}$ serves as electrodes while tetraoxosulphate (VI) acid act as electrolyte. Auto electricians servicing lead accumulator cells dispose of electrolytes indiscriminately into the vicinity. The highest $\mathrm{Pb}$ (161.07) $\mu \mathrm{gg}^{-1}$ observed in the current study was below that at Apir auto-mechanic workshop soil $\left(283 \mathrm{mgkg}^{-1}\right)$ in Makurdi the capital of Benue State and Adekaa $\left(665 \mathrm{mgkg}^{-1}\right)$ in Gboko also in Benue State (Pam et al., 2013). Cadmium is non-essential and classified among the deleterious hazardous metals (Holan and Volesky, 1994). The half -life is about 18 years (Forstner, 1995). Soil Cd was below those found in Apir auto-mechanic workshops (11.74 - 21.84) $\mathrm{mgkg}^{-1}$ and Gboko auto-mechanic workshops (7.04 - 21.6) $\mathrm{mgkg}^{-1}$ (Pam et al., 2013). Again soil $\mathrm{Cd}\left(0.41\right.$ - 17.23) $\mathrm{mgkg}^{-1}$ and $\mathrm{Pb}$ (18.25 - 15100) $\mathrm{mgkg}^{-1}$ levels observed in a study conducted by (Adelekan \& Abegunde, 2011) showed levels above the current study. The levels of $\mathrm{Cd}$ recorded might have originated from lubricating oils, tire wear and metal alloys used as hardners in engine parts (Dabkowska- Naskret, 2004). Lack of proper disposal of these substances has been implicated for the existence of $\mathrm{Pb}, \mathrm{Cd}$ and $\mathrm{As}$ in the environment (Igbwe et al., 2006). Table $2 \&$ Table 3.

Table 2: Pollution Grades of Geo-accumulation Index (I-geo) of Metals (Muller, 1969)

\begin{tabular}{|l|l|l|}
\hline I-geo class & I-geo value & Contamination Intensity \\
\hline 0 & I-geo $<0$ & Uncontaminated \\
\hline 1 & $0<$ I-geo $<1$ & $\begin{array}{l}\text { Uncontaminated to moderately con- } \\
\text { taminated }\end{array}$ \\
\hline 2 & $1<$ I-geo $<2$ & Moderately contaminated \\
\hline 3 & $2<$ I-geo $<3$ & Moderately to heavily contaminated \\
\hline 4 & $3<$ I-geo $<4$ & Heavily contaminated \\
\hline 5 & $4<$ I-geo $<5$ & Heavily to extremely contaminated \\
\hline 6 & $5<$ I-geo & Extremely \\
\hline
\end{tabular}

Table 1: Hazardous Metal Contents of Auto-Mechanic Workshop Soils and Background Soils from Selected Study Sites in $\mu g^{-1}$

\begin{tabular}{|l|l|l|l|l|l|l|l|l|l|l|l|l|l|l|l|l|l|l|}
\hline \multicolumn{4}{|l|}{$\begin{array}{l}\text { Suame Auto-Mechanic } \\
\text { Workshop Soil }\end{array}$} & \multicolumn{4}{l|}{$\begin{array}{l}\text { Suame Background } \\
\text { Soil }\end{array}$} & \multicolumn{4}{l|}{$\begin{array}{l}\text { Asafo Auto-Mechanic } \\
\text { Workshop Soil }\end{array}$} & \multicolumn{1}{l|}{ Asafo Background } & \multicolumn{4}{l|}{$\begin{array}{l}\text { Mampong Auto- } \\
\text { Mechanic Workshop }\end{array}$} & $\begin{array}{l}\text { Mampong } \\
\text { Background Soil }\end{array}$ \\
\hline $\mathrm{Pb}$ & $\mathrm{Cd}$ & $\mathrm{As}$ & $\mathrm{Pb}$ & $\mathrm{Cd}$ & $\mathrm{As}$ & $\mathrm{Pb}$ & $\mathrm{Cd}$ & $\mathrm{As}$ & $\mathrm{Pb}$ & $\mathrm{Cd}$ & $\mathrm{As}$ & $\mathrm{Pb}$ & $\mathrm{Cd}$ & $\mathrm{As}$ & $\mathrm{Pb}$ & $\mathrm{Cd}$ & $\mathrm{As}$ \\
\hline 161.07 & 0.43 & 0.12 & 6.62 & 0.03 & 0.91 & 169.79 & 2.10 & 1.80 & 6.62 & 0.43 & 0.91 & 17.63 & 1.80 & 0.11 & 11.54 & 0.60 & 0.29 \\
\hline
\end{tabular}


Table 3: Geo-accumulation Index $\left(\mathrm{I}_{\mathrm{geo}}\right)$ and Classification

\begin{tabular}{|c|c|c|c|}
\hline SITES & $\mathrm{Pb}$ & $\mathrm{Cd}$ & As \\
\hline Suame & $\begin{array}{c}2.79 \\
\text { Moderately to } \\
\text { heavily contam- } \\
\text { inated }\end{array}$ & $\begin{array}{c}2.26 \\
\text { Moderately to } \\
\text { heavily contam- } \\
\text { inated }\end{array}$ & $\begin{array}{c}-2.43 \\
\text { Uncontaminated }\end{array}$ \\
\hline Asafo & $\begin{array}{c}2.84 \\
\text { Moderately to } \\
\text { heavily contam- } \\
\text { inated }\end{array}$ & $\begin{array}{c}1.18 \\
\text { Moderately } \\
\text { contaminated }\end{array}$ & $\begin{array}{c}0.28 \\
\text { Uncontaminated }\end{array}$ \\
\hline Mampong & $\begin{array}{c}0.02 \\
\text { Uncontaminated }\end{array}$ & $\begin{array}{c}0.69 \\
\text { Uncontaminated }\end{array}$ & $\begin{array}{c}-1.38 \\
\text { Uncontaminated }\end{array}$ \\
\hline
\end{tabular}

Geo-accumulation index (Igeo) classification by Muller, (1969) was employed to determine the extent of metal pollution of the soils. The three (3) auto-mechanic workshop soils showed differences in pollution levels. Suame auto-mechanic workshop (SAWS) was found to be uncontaminated with As $\left(\mathrm{I}_{\text {geo }}=-2.43\right)$. The soil was rather observed to be polluted with $\mathrm{Pb}\left(\mathrm{I}_{\text {geo }}=2.79\right)$ and $\mathrm{Cd}\left(\mathrm{I}_{\mathrm{geo}}=2.26\right)$ and might be classified as "Moderately to heavily contaminated". Asafo auto-mechanic workshop soil was not contaminated with As $\left(\mathrm{I}_{\text {geo }}=0.28\right)$ but contaminated with $\mathrm{Pb}$ $\left(\mathrm{I}_{\text {geo }}=2.84\right)$ and $\mathrm{Cd}\left(\mathrm{I}_{\text {geo }}=1.18\right)$. Mampong auto-mechanic workshop soil had these $\mathrm{I}_{\text {geo }}$ values for the various metals: $\mathrm{Pb}\left(\mathrm{I}_{\text {geo }}=\right.$ $0.02), \mathrm{Cd}\left(\mathrm{I}_{\mathrm{geo}}=0.69\right)$ and As $\left(\mathrm{I}_{\mathrm{geo}}=-1.38\right)$. The soil was thus uncontaminated.

\section{Hazardous metal content in Medicinal Plants}

Medicinal plants with a tendency of accumulating metals can be blamed for dietary uptake of deleterious hazardous metals by human and animals. In minute amounts metals are needed for life's processes. For example, humans require different concentrations of hazardous metals such as iron, cobalt, copper, manganese, molybdenum and zinc. Also copper is essential to the human body because it is a component of many enzyme systems such as cytochrome, oxidase and ceruloplas- min, an iron-oxidizing enzyme in blood (Sarpong et al., 2012). But excessive amounts are toxic to organisms. The medicinal plant samples exhibited differences in $\mathrm{Pb}$ concentration. Auto-mechanic soils demonstrated higher $\mathrm{Pb}$ levels than background soils. Lead amounts in the auto-mechanic soils ranged from (1.64 - 196.92) $\mu \mathrm{gg}^{-1}$ while that of background soils was (0.01 - 19.62) $\mu_{\mathrm{gg}^{-1}}$. Jatropha curcas (MAWS) recorded highest $\mathrm{Pb}(196.92) \mathrm{ggg}^{-1}$ and the lowest was in Spondias mombin (1.64) $\mu \mathrm{gg}^{-1}$ (AAWS). Concerning $\mathrm{Pb}$ in the background soils Terminalia catappa (19.62) $\mu \mathrm{gg}^{-1}$ (MBS) and Cola nitida (0.01) $\mu g^{-1}$ (SBS) had the highest and lowest $\mathrm{Pb}$ levels respective-

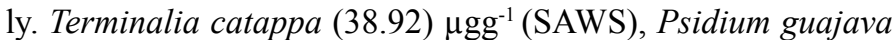
(20.88) $\mu g^{-1}$ (SAWS), Jatropha curcas (196.92) $\mu g^{-1}$ (MAWS), Anarcadium occidentale (38.20) $\mu \mathrm{gg}^{-1}$ (MAWS) and Psidium guajava (108.28) $\mu \mathrm{gg}^{-1}$ (MAWS) had $\mathrm{Pb}$ concentrations above the normal range $(0.2-20) \mu g^{-1}$ (Table 4). However, Terminalia catappa (38.92) $\mathrm{\mu gg}^{-1}$ (SAWS), Jatropha curcas (196.92) $\mathrm{\mu gg}^{-1}$ (MAWS), Anarcadium occidentale (38.20) $\mu \mathrm{gg}^{-1}$ (MAWS) and

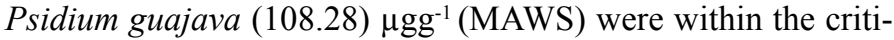
cal plant concentration beyond which the medicinal plant could be toxic to humans. With exception of the aforementioned plants the rest of the medicinal plant samples (Alstonia boonei de Wild, Spondias mombin, Mangifera indica, Azadirachta indica, Milletia thonningia, Anarcadium occidentale and Psidium guajava Linn (SAWS) were within the acceptable $\mathrm{Pb}$ range of $(0.2-20)$ $\mu \mathrm{gg}^{-1}$.

Table 5: Concentration ranges of Hazardous metals $\left(\mu \mathrm{gg}^{-1}\right)$ in Plants and Critical Plants Concentrations

\begin{tabular}{|c|c|c|c|}
\hline $\begin{array}{c}\text { Hazardous } \\
\text { Metal }\end{array}$ & $\begin{array}{c}\text { Normal range in } \\
\text { Soils }\end{array}$ & $\begin{array}{c}\text { Normal range } \\
\text { in Plants }\end{array}$ & $\begin{array}{c}\text { Critical Plant } \\
\text { Concentration }\end{array}$ \\
\hline $\mathrm{Pb}$ & $2-300$ & 0.2 & $30-300$ \\
\hline $\mathrm{Cd}$ & $0.01-2$ & $0.1-2.4$ & $5-30$ \\
\hline $\mathrm{As}$ & $0.1-40$ & $0.02-7$ & $5-20$ \\
\hline
\end{tabular}

Radojevic and Bashkin (2006)

Table 4: Hazardous Metal Content $\left(\mu \mathrm{gg}^{-1}\right)$ in the bark of Medicinal plants from the three (3) Sites

\begin{tabular}{|c|c|c|c|c|c|c|c|c|c|c|c|c|c|c|c|c|c|c|}
\hline \multirow[t]{2}{*}{ Medicinal Plants } & \multicolumn{3}{|c|}{$\begin{array}{l}\text { Suame Auto-Mecha- } \\
\text { nic Workshop Soil }\end{array}$} & \multicolumn{3}{|c|}{$\begin{array}{l}\text { Suame Back- } \\
\text { ground Soil }\end{array}$} & \multicolumn{3}{|c|}{$\begin{array}{l}\text { Asafo Auto-Me- } \\
\text { chanic Workshop } \\
\text { Soil }\end{array}$} & \multicolumn{3}{|c|}{$\begin{array}{l}\text { Asafo Background } \\
\text { Soil }\end{array}$} & \multicolumn{3}{|c|}{$\begin{array}{l}\text { Mampong Auto-Me- } \\
\text { chanic Workshop } \\
\text { Soil }\end{array}$} & \multicolumn{3}{|c|}{$\begin{array}{l}\text { Mampong Back- } \\
\text { ground Soil }\end{array}$} \\
\hline & $\mathrm{Pb}$ & $\mathrm{Cd}$ & As & $\mathrm{Pb}$ & $\mathrm{Cd}$ & As & $\mathrm{Pb}$ & $\mathrm{Cd}$ & As & $\mathrm{Pb}$ & $\mathrm{Cd}$ & As & $\mathrm{Pb}$ & $\mathrm{Cd}$ & As & $\mathrm{Pb}$ & $\mathrm{Cd}$ & As \\
\hline $\begin{array}{l}\text { Alstonei boonei de } \\
\text { Wild }\end{array}$ & 14.32 & 1.16 & 0.32 & 0.09 & 0.01 & 0.01 & 6.68 & 1.32 & 0.06 & 0.12 & 0.03 & 0.01 & 5.92 & 0.32 & 0.09 & 1.72 & 0.03 & 0.19 \\
\hline Spondias mombin & 15.30 & 1.63 & 0.30 & 0.04 & 0.02 & 0.01 & 1.64 & 0.56 & 0.12 & 0.07 & 0.02 & 0.01 & 13.72 & 0.17 & 0.04 & 2.92 & 0.01 & 0.12 \\
\hline Mangifera indica & 13.25 & 1.75 & 0.09 & 0.06 & 0.03 & 0.01 & 18.16 & 0.36 & 0.13 & 0.04 & 0.02 & 0.01 & 6.62 & 2.44 & 0.16 & 5.44 & 0.06 & 0.14 \\
\hline Terminalia catappa & 38.92 & 1.02 & 0.30 & 0.05 & 0.02 & 0.01 & 8.64 & 0.97 & 0.36 & 0.07 & 0.04 & 0.01 & 9.56 & 2.37 & 0.13 & 19.62 & 0.12 & 0.06 \\
\hline Azadirachta indica & 19.23 & 1.44 & 0.21 & 13.26 & 0.13 & 0.04 & 10.32 & 0.09 & 0.03 & 0.11 & 0.03 & 0.03 & 17.36 & 0.68 & 0.10 & 5.08 & 0.36 & 0.05 \\
\hline Milletia thonningia & 7.64 & 0.41 & 0.10 & 2.16 & 0.21 & 0.03 & 10.63 & 0.32 & 0.10 & 12.26 & 0.09 & 0.04 & 12.04 & 1.88 & 0.08 & 8.48 & 0.56 & 0.08 \\
\hline Jatropha curcas & 2.48 & 0.60 & 0.20 & 0.43 & 0.05 & 0.02 & 12.84 & 2.16 & 0.61 & 3.45 & 0.18 & 0.04 & 196.92 & 2.36 & 0.11 & 3.24 & 0.08 & 0.13 \\
\hline Cola nitida & 3.32 & 0.77 & 0.03 & 0.01 & 0.02 & 0.01 & 2.75 & 0.56 & 0.21 & 0.42 & 0.06 & 0.02 & 19.24 & 1.33 & 0.05 & 18.56 & 0.20 & 0.06 \\
\hline $\begin{array}{l}\text { Anarcadium occi- } \\
\text { dentale }\end{array}$ & 9.12 & 0.64 & 0.24 & 12.42 & 0.59 & 0.01 & 5.23 & 1.24 & 0.18 & 0.02 & 0.03 & 0.01 & 38.20 & 0.68 & 0.23 & 6.24 & 0.16 & 0.04 \\
\hline $\begin{array}{l}\text { Psidium guajava } \\
\text { Linn }\end{array}$ & 20.88 & 0.96 & 0.35 & 1.26 & 0.11 & 0.03 & 1.98 & 0.46 & 0.05 & 13.28 & 0.03 & 0.09 & 108.26 & 0.92 & 0.09 & 2.24 & 0.03 & 0.04 \\
\hline
\end{tabular}

NB: Suame Auto-mechanic Workshop Soil (SAWS); Suame Background Soil (SBS); Asafo Auto-mechanic Workshop Soil (AAWS); Asafo Background Soil (ABS); Mampong Auto-mechanic Workshop Soil (MAWS); Mampong Background Soil (MBS) 
Highest level of Cd was contained in Magnifera indica $\left(2.44 \mathrm{ggg}^{-1}\right)$ (MWS) while the lowest was in both Alstonia boonei $\left(0.01 \mu \mathrm{gg}^{-1}\right) \mathrm{SBS}$ and Spondias mombin $\left(0.01 \mu \mathrm{gg}^{-1}\right)(\mathrm{MBS})$.The $\mathrm{Cd}$ content in medicinal plants was in the range $(0.01-2.44)$ $\mu \mathrm{gg}^{-1}$. Except Magnifera indica (MWS) all the medicinal plants were within the acceptable range $(0.1-2.4){\mu g g g^{-1}}^{-}$. Cadmium levels were SWS $(0.64-1.75) \mu \mathrm{gg}^{-1}$; SBS $(0.01-0.59) \mu \mathrm{gg}^{-1}$; AAS (0.09 - 2.16) $\mu \mathrm{gg}^{-1} ; \mu \mathrm{gg}^{-1} \mathrm{ABS}\left(0.03\right.$ - 0.18) $\mu \mathrm{gg}^{-1} \mathrm{MWS}(0.17$ - 2.37) $\mu \mathrm{gg}^{-1}$ and MBS $(0.01-0.56) \mu \mathrm{gg}^{-1}$.Cadmium amounts were less than critical plant concentration $(5-30) \mu \mathrm{gg}^{-1}$. The study showed that the medicinal plant samples from both auto-mechanic and backgrounds sites (Table 5) would not be toxic to humans and animals.

Table 5 revealed different As loads in the medicinal plants from the three sites. Suame auto-mechanic workshop had As load of $(0.03-0.35) \mu \mathrm{gg}^{-1}$; SBS $(0.01-0.04) \mu \mathrm{gg}^{-1}$; AWS $(0.05-0.61) \mu \mathrm{gg}^{-1} ;$ ABS $(0.01-0.09) \mu \mathrm{gg}^{-1} ;$ MWS $(0.04-0.23)$ $\mu g^{-1}$; MBS (0.04 - 0.19) $\mu \mathrm{gg}^{-1}$. Highest As level (0.61) $\mu \mathrm{gg}^{-1}$ was in Jatropha curcas. The lowest As value (0.01) $\mu g^{-1}$ was in Alstonei boonei de Wild (SBS), Spondias mombin (SBS), Terminalia catappa (SBS), Cola nitida (SBS), and Anarcadium occidentale (ABS). Arsenic levels were below the normal range $(0.02-7) \mu \mathrm{gg}^{-1}$ and $(5-20) \mu \mathrm{gg}^{-1}$ which was the critical plant concentration (Table 4). The medicinal plants analyzed pose no health threat to humans and animals.

\section{Transfer ratio}

The transfer ratio for $\mathrm{Pb}$ in SAWS was higher than SBS for all the medicinal plants except Anarcadium occidentale Linn (1.88) (SBS). The transfer ratio for $\mathrm{Pb}$ in AAWS was lower than ABS. The highest transfer ratio for $\mathrm{Pb}$ was 3.02 for Anarcadium occidentale Linn (ABS). Mampong auto-mechanic workshop had the highest transfer ratio for $\mathrm{Pb}$ with value 33.58 in Alstonia boonei de Wilde. The lowest transfer ratio (0.01) for $\mathrm{Pb}$ was detected in Alstonei boonei de Wild (SBS), Spondias mombin
(SBS), and Mangifera indica (SBS). (Table 6).

Medicinal plants (SAWS) had transfer ratio for $\mathrm{Cd}$ higher than SBS. The highest ratio was (4.07) in Magnifera indica (SAWS) while the lowest was (0.33) in Alstonia boonei (SBS). Apart from Milletia thongii (0.21) (ABS) the transfer ratio of Cd was higher in all the medicinal plant samples in AAWS than ABS. The highest transfer ratio was (0.46) (AAWS).

The transfer ratio for As was highest in Psidium guajava (SAWS) with value (2.92). Alstonei boonei de Wild (SAWS) and Spondias mombin (SAWS) had a value (2.67). Cola nitida possessed transfer ratio (0.25) (SAWS). This lowest value was higher than all the medicinal plants in SBS except Azadirachta indica (0.43) (ABS). Also lowest transfer ratio of As in SAWS was higher than AAWS except Jatropha curcas (0.34), Milletia thonningia (ABS) (0.33), Jatropha curcas (0.33), Psidium guajava Linn (0.75) (ABS). Transfer ratio of As in medicinal plant samples from MAWS had higher values than those in MBS. Anarcadium occidentale (MAWS) recorded (2.09) the highest, with the lowest (0.36) in Spondias mombin (MAWS).The lowest of As in MAWS was highest than all except Alstonia boonei de Wilde (0.66) (ABS), Spondias mombin (0.41) (ABS), Mangifera indica (0.48)(ABS) and Jatropha curcas $(0.45)(\mathrm{ABS})$.

\section{Conclusion}

Release of hazardous metals into the ecosystem either through natural or anthropogenic processes should be of concern to all as they built up in plant parts and eventually finds their way into the food chain. The presence of $\mathrm{Pb}, \mathrm{Cd}$ and As may cause acidification of soils. Microorganisms find it difficult to thrive on these soils. Locally, herbal manufacturers employ medicinal plants in synthesizing their products. With these medicinal plants contaminated, the final products would be unwholesome hence unfit for human consumption. The medicinal plants must be screened for the presence of these toxic contaminants before use.

Table 6: Transfer Ratio

\begin{tabular}{|c|c|c|c|c|c|c|c|c|c|c|c|c|c|c|c|c|c|c|}
\hline \multirow[t]{3}{*}{ Medicinal Plant } & \multicolumn{3}{|c|}{$\begin{array}{l}\text { Suame Auto-Me- } \\
\text { chanic Workshop } \\
\text { Soil }\end{array}$} & \multicolumn{3}{|c|}{$\begin{array}{l}\text { Suame Back- } \\
\text { ground Soil }\end{array}$} & \multicolumn{3}{|c|}{$\begin{array}{l}\text { Asafo Auto-Me- } \\
\text { chanic Workshop } \\
\text { Soil }\end{array}$} & \multicolumn{3}{|c|}{$\begin{array}{c}\text { Asafo Background } \\
\text { Soil }\end{array}$} & \multicolumn{3}{|c|}{$\begin{array}{c}\text { Mampong } \\
\text { Auto-Mechanic } \\
\text { Workshop Soil }\end{array}$} & \multicolumn{3}{|c|}{$\begin{array}{l}\text { Mampong Back- } \\
\text { ground Soil }\end{array}$} \\
\hline & \multicolumn{18}{|c|}{ TRANSFER RATIO } \\
\hline & $\mathrm{Pb}$ & $\mathrm{Cd}$ & As & $\mathrm{Pb}$ & $\mathrm{Cd}$ & As & $\mathrm{Pb}$ & $\mathrm{Cd}$ & As & $\mathrm{Pb}$ & $\mathrm{Cd}$ & As & $\mathrm{Pb}$ & $\mathrm{Cd}$ & As & $\mathrm{Pb}$ & $\mathrm{Cd}$ & As \\
\hline Alstonei boonei de Wild & 0.09 & 2.70 & 2.67 & 0.01 & 0.33 & 0.01 & 0.04 & 0.63 & 0.03 & 0.02 & 0.07 & 0.08 & 33.58 & 0.18 & 0.82 & 0.15 & 0.07 & 0.66 \\
\hline Spondias mombin & 0.10 & 3.79 & 2.67 & 0.01 & 0.67 & 0.01 & 0.01 & 0.28 & 0.07 & 0.01 & 0.05 & 0.08 & 0.78 & 0.09 & 0.36 & 0.25 & 0.02 & 0.41 \\
\hline Mangifera indica & 0.08 & 4.07 & 0.75 & 0.01 & 1.00 & 0.01 & 0.11 & 0.17 & 0.07 & 0.01 & 0.05 & 0.08 & 0.38 & 1.36 & 1.45 & 0.47 & 0.10 & 0.48 \\
\hline Terminalia catappa & 0.24 & 2.37 & 2.5 & 0.01 & 0.67 & 0.01 & 0.05 & 0.46 & 0.20 & 0.01 & 0.09 & 0.08 & 0.54 & 1.32 & 1.18 & 1.70 & 0.20 & 0.21 \\
\hline Azadirachta indica & 0.12 & 3.34 & 1.75 & 2.00 & 0.33 & 0.43 & 0.06 & 0.04 & 0.02 & 0.02 & 0.07 & 0.25 & 0.98 & 0.38 & 0.91 & 0.44 & 0.60 & 0.17 \\
\hline Milletia thonningia & 0.05 & 0.95 & 0.83 & 0.33 & 0.67 & 0.03 & 0.06 & 0.15 & 0.18 & 1.85 & 0.21 & 0.33 & 0.68 & 1.04 & 0.73 & 0.73 & 0.90 & 0.28 \\
\hline Jatropha curcas & 0.02 & 1.39 & 1.67 & 0.07 & 1.67 & 0.02 & 0.08 & 1.02 & 0.34 & 0.52 & 0.42 & 0.33 & 11.17 & 1.31 & 1.00 & 0.28 & 0.33 & 0.45 \\
\hline Cola nitida & 0.02 & 1.79 & 0.25 & 0.002 & 0.67 & 0.01 & 0.02 & 0.27 & 0.12 & 0.06 & 0.14 & 0.17 & 1.09 & 0.73 & 0.46 & 1.61 & 0.27 & 0.21 \\
\hline $\begin{array}{l}\text { Anarcadium occidentale } \\
\text { Linn }\end{array}$ & 0.06 & 1.49 & 2.00 & 1.88 & 1.97 & 0.01 & 0.03 & 0.62 & 0.10 & 3.02 & 0.07 & 0.08 & 2.17 & 0.38 & 2.09 & 0.54 & 0.05 & 0.14 \\
\hline Psidium guajava Linn & 0.13 & 2.23 & 2.92 & 0.19 & 0.66 & 0.03 & 0.01 & 0.19 & 0.03 & 2.01 & 0.07 & 0.75 & 6.18 & 0.51 & 0.82 & 0.94 & 0.8 & 0.14 \\
\hline
\end{tabular}

NB: Suame Auto-mechanic Workshop Soil (SAWS); Suame Background Soil (SBS); Asafo Auto-mechanic Workshop Soil (AAWS); Asafo Background Soil (ABS); Mampong Auto-mechanic Workshop Soil (MAWS); Mampong Background Soil (MBS) 


\section{Reference}

1. Adewole, M.B., Uchegbu, L.U. Properties of Soils and plants uptake within the vicinity of selected Automobile workshops in Ile-Ife Southwestern, Nigeria. (2010) Ethiopian J Environ Studies Manage 3(3): 31 35 .

2. Adelekan, B.A., Abengude, K.D. Heavy Metals Contamination of Soil and Groundwater at automobile mechanic villages in Ibadan, Nigeria. (2011) Intl J Physical Sci 6(5): 1045-1058.

3. Adriano, D.C. Trace elements in terrestrial environment. $2^{\text {nd }}$ Ed. (2001) New York, Springer.

4. Agyarko, K., Dartey, E., Berlinger, B. Metal levels in some refuse dump soils and plants in Ghana. (2010) Plant Soil Environ 56(5): 244 251.

5. Akoto, O., Ephraim, J.H., Darko, G. Heavy metal pollution in surface soils in the vicinity of abundant railway servicing workshop in Kumasi, Ghana. (2008) Int J Environ Res 2(4): 359-364.

6. Chojnacka, K., Chojnacki, A., Gorecka, H. Bioavailability of heavy metals from polluted soils to plants. (2005) Sci Total Environ 337: $175-182$.

7. Committee on Development and Intellectual Property (CDIP).Country Study on Innovation, Intellectual Property and the Informal Economy. (2014) Traditional Herbal Medicine in Ghana, $13^{\text {th }}$ Session, Geneva.

8. Citifmonline.com. Doctor-patient ratio alarming. (2014) Health Director.

9. Dabowski-Naskre, H. The mobility of heavy metals in urban soils used for food production in Poland. (2004) Land Contamination \& Reclamation 12(3): 205-212.

10. Dartey, E., Berlinger B., Thomassen, Y., et al. Bioaccessibility of lead in airborne particulates from car battery repair work. (2014) Environ Sci Processes Impacts 16(12): 2782-2788.

11. D'Amore, J.J., Al-Abed, K.G., Scheckel, K.G., et al. "Methods for Speciation of Metals in Soils: a review". (2005) Journal Environ Qual 34(5): 1707-1745.

12. Forstner, U. Land Contamination by Metals: Global Scope and Magnitude of Problem. (1995) In book: Metal Speciation and Contamination of soil. Allen, H.E., Huang, C.P., Bailey, G.W., Bowers AR (eds) CRC Press: Boca Raton 1-33.

13. Ghana districts. A repository of all districts in the republic of Ghana. (2012)

14. Holan, Z.R., Volesky, B. Biosorption of lead and nickel by biomass of marine algae. (1994) Biotechnol Bioeng 43(11): 1001-1009.

15. Igbwe, C.M.A., Isirimah, N.O., Igwe, C., et al. Characteristics levels of heavy metals in soil Profile of automobile mechanic waste dumps. (2006) Environmentalist 26: 123-128.
16. International Programme on Chemical safety (IPCS) Environmental Health Criteria 224 (1980). World Health Organization, Geneva.

17. Krishna, A.K., Govil, P.K. Soil contamination due to heavy metals from industrial area of Surat Gujarat, Western India. (2007) Environ Monit Assess 124(1-3): 263-275.

18. Kirpichtchikova, T.A., Manceau, A., Spadini, L., et al. "Speciation and solubility of heavy metals in contaminated soil using X-ray microfluorescence, EXAFS spectroscopy, chemical extraction, and thermodynamic modeling". (2006) Geochimica et Cosmochimica Acta 70(9): 2163-2190.

19. Sarpong, K., Dartey, E., Boateng, G.O., et al. Profile of hazardous metals in twenty (20) selected medicinal plants samples sold at Kumasi central market, Ashanti region, Ghana. (2012) Global Adv J Edu Res \& Rev 1(1): 4-9.

20. Radojevic, M., Bashkin, V.N. Practical Environmental Analysis. The Royal Society of Chemistry. (2006) Cambridge 389.

21. Muller, G.'Index of geo-accumulation in sediments of Rhine River", (1969) Geochem J 2(3): 108-118.

22. O’Neil, P. "Heavy Metals in Soils". (1990) John Wiley 83-89.

23. Pam, A.A., Sha'Ato, R., Offem, J.O., et al. Evaluation of heavy metals in soils around auto mechanic workshop clusters in Gboko and Makurdi, Central Nigeria. (2013) J Environ Chem Ecotoxicol 5(11): 298-306.

24. Schmitt, C.J., Brumbaugh, W.G."National contaminant biomonitoring program: concentrations of $\mathrm{As}, \mathrm{Cd}, \mathrm{Cu}, \mathrm{Pb}, \mathrm{Hg}, \mathrm{Se}$, and $\mathrm{Zn}$ in US fresh water, “1976-1984”. (1990) Arch Environ Contam \& Toxicol 19: 731-747.

25. Senesi, G.S., Baldassare, G., Senesi, N., et al. Trace Element Inputs into Soils by Anthropogenic Activities and Implications for Human Health. (1999) Chemosphere 39(2): 343-377.

26. Sofianska, E., Michailidis, K., Mladenova, V., et al. Multivariate statistical and GIS-based approach to identify heavy metal sources in soils of Drama Plain, Northern Greece. (2013) Geosci J 131-132.

27. Sobolev, D., Begonia, M.F. Effects of Heavy Metal Contamination upon Soil Microbes: Lead-induced changes in General and Denitrifying Microbial Communities as Evidenced by Molecular Markers. (2008) Int J Environ Res Public Health 5(5): 450-456.

28. Wuana, R.A., Okieimen, F.E. "Heavy Metals in Contaminated Soils: A Review of Sources, Chemistry, Risks and Best Available Strategies for Remediation. (2011) ISRN Ecolo gy 20.

29. Wild, A. Soil and the Environment: An Introduction. (1995) Cambridge University Press 109-165.
Ommega Online Publishers

Journal Title: Journal of Environment and Health Science (JEHS)

Journal Short Name: J Environ Health Sci
Journal ISSN: 2378-6841

E-mail: environmentalscience@ommegaonline.org

Website: www.ommegaonline.org 